\title{
Systemic Acquired Resistance in Canola Is Linked with Pathogenesis- Related Gene Expression and Requires Salicylic Acid
}

\author{
Shobha D. Potlakayala, Darwin W. Reed, Patrick S. Covello, and Pierre R. Fobert
}

First author: Department of Biology, University of Saskatchewan, Saskatoon, SK S7N 5E2, Canada; second and third authors: Plant Natural Products Group, National Research Council, Plant Biotechnology Institute, 110 Gymnasium Place, Saskatoon, SK S7N 0W9, Canada; and fourth author: Protein Research Group, National Research Council, Plant Biotechnology Institute, 110 Gymnasium Place, Saskatoon, SK S7N 0W9, Canada.

Accepted for publication 2 December 2006.

\begin{abstract}
Potlakayala, S. D., Reed, D. W., Covello, P. S., and Fobert, P. R. 2007. Systemic acquired resistance in canola is linked with pathogenesis-related gene expression and requires salicylic acid. Phytopathology 97:794-802.

Systemic acquired resistance (SAR) is an induced defense response that confers long-lasting protection against a broad range of microbial pathogens. Here we show that treatment of Brassica napus plants with the SAR-inducing chemical benzo-(1,2,3)-thiadiazole-7-carbothioic acid Smethyl ester (BTH) significantly enhanced resistance against virulent strains of the bacterial pathogen Pseudomonas syringae pv. maculicola and the fungal pathogen Leptosphaeria maculans. Localized preinocu-

effective against $P$. syringae pv. maculicola, even when given more than 3 weeks prior to the secondary challenge. The pretreatments also led to the accumulation of pathogenesis-related (PR) genes, including BnPR-1 and $B n P R-2$, with higher levels of transcripts observed in the BTHtreatment material. B. napus plants expressing a bacterial salicylate hydroxylase transgene $(N a h G)$ that metabolizes salicylic acid to catechol were substantially compromised in SAR and accumulated reduced levels of PR gene transcripts when compared with untransformed controls. Thus, SAR in B. napus displays many of the hallmarks of classical SAR including long lasting and broad host range resistance, association with $\mathrm{PR}$ gene activation, and a requirement for salicylic acid.
\end{abstract} lation of plants with an avirulent strain of $P$. syringae pv. maculicola also enhanced resistance to these pathogens but was not as effective as BTH treatment. Single applications of either SAR-inducing pretreatment were
Additional keywords: benzothiadiazole, blackleg, defense mechanisms, signaling.
Systemic acquired resistance (SAR) is an induced disease-resistance state that is achieved in uninfected parts of a plant following localized exposure to pathogens that cause some form of cell death at the site of infection, such as the hypersensitive response (HR) associated with $R$-gene-mediated resistance or diseaseinduced necrosis $(7,28)$. SAR has been reported in several dicot and monocot species and is effective against a broad range of viruses, bacteria, oomycetes, and fungi $(18,30)$. However, SAR is not effective against all pathogens and the spectrum of resistance varies between plant species (13).

Characteristic features of SAR include the requirement for the phenolic signaling molecule salicylic acid (SA) and an association with the induction of pathogenesis-related (PR) genes and proteins (7). Following exposure to pathogens, SA levels increase substantially at the site of infection (locally) and to a lesser extent, in uninfected (systemic) tissues $(28,37)$. SA accumulation is necessary for SAR, as plants unable to accumulate SA, either through transgenic expression of a bacterial salicylate hydroxylase $(N a h G)$ gene that metabolizes SA to catechol $(5,11,21)$ or loss-of-function mutations that prevent SA biosynthesis (25), are compromised in SAR. Conversely, exogenous application of SA or its functional analogs benzo $(1,2,3)$ thiadiazole-7-carbothioic acid (S) methyl ester (BTH) and 2,6-dichloroisonicotinic acid (INA) lead to enhanced resistance to pathogens $(6,9,20)$.

Increases in SA levels also trigger the local and systemic expression of a subset of PR genes also known as SAR genes (33,

Corresponding author: P. R. Fobert; E-mail address: Pierre.Fobert@nrc-cnrc.gc.ca

doi:10.1094/PHYTO-97-7-0794

(c) 2007, Her Majesty the Queen in Right of Canada, National Research Council of Canada.
35). The timing of SAR gene expression correlates with the onset and duration of SAR $(33,35)$, and accumulation of SAR gene transcripts is compromised in NahG plants $(5,21)$. Although the contribution of individual PR or SAR genes to disease resistance remains unclear (30), their expression provides useful markers for SAR. In particular, $P R-1, P R-2$, and $P R-5$ have been extensively used as markers for the onset of SAR in Arabidopsis and tobacco (7).

Brassica napus is an economically important crop that is grown worldwide and is susceptible to many bacterial and fungal diseases resulting in huge agronomic losses (15). In particular, blackleg disease caused by the ascomycete Leptosphaeria maculans is one of the most serious diseases of oilseed Brassicas, including canola grade $B$. napus and $B$. rapa. Nevertheless, SAR has yet to be carefully analyzed in oilseed Brassicas. Mahuku et al. (23) demonstrated that disease lesions caused by a highly virulent strain of $L$. maculans were reduced significantly when adjacent leaves had been previously infected with a weakly virulent strain. Treatment of $B$. napus with menadione sodium bisulphate (MSB), which appears to induce a form of systemic resistance distinct from SAR, has been shown to be effective against L. maculans (1), while application of BTH has been shown to be effective at reducing downy mildew caused by Peronospora parasitica in B. oleracea $(12,17,38)$ and to provide some control of damping-off caused by Rhizoctonia solani in B. napus (17). BTH treatment of $B$. oleracea seedlings induced $\beta-1,3$ glucanase activity and PR-2 protein accumulation, but had no effect on chitinase activity or the levels of PR-1, PR-3, and PR-5 (38).

The objectives of this study were to assess the effectiveness of SAR against $L$. maculans and to determine whether SAR in B. napus is associated with PR gene expression and requires SA. As a reference point, SAR against the bacterial pathogen Pseudo- 
monas syringae pv. maculicola was also assessed. For both pathogens, protection conferred by preinoculation with a necrogenic pathogen was compared to that induced by treatment with BTH.

\section{MATERIALS AND METHODS}

Plant growth conditions. B. napus (cv. Westar) plants were grown in the greenhouse at $22^{\circ} \mathrm{C}$ with 18 -h daylight at $190 \mu \mathrm{E}$ $\mathrm{m}^{-2} \mathrm{~s}^{-1}$. Seedlings used for fungal disease testing were grown in cabinets at similar temperature and light conditions with $50 \%$ relative humidity.

Production of transgenic B. napus expressing the NahG gene. B. napus (Westar) plants were transformed by Agrobacterium-mediated transformation according to Tsang et al. (32). The plasmid used for transformation contained the $N a h G$ gene driven by the Cauliflower mosaic virus (CaMV) 35S promoter described by Liu et al. (22). Rooted plants were transferred to pots for seed and tested for $N a h G$ gene expression by northern blot analysis. All transgenic $N a h G$ plants used in this study were from the same transgenic event. To ensure that all individuals analyzed were indeed genetically transformed, a cotyledon from each was tested for the expression of the Escherichia coli uidA (GUS) gene which was incorporated into the T-DNA (27) and encodes a $\beta$-D-glucuronidase.

Chemical treatment. Ten-day-old cotyledons (for fungal disease testing), 4-week-old plants (for bacterial disease testing), or plants at different ages (for time course studies) were sprayed with a freshly made aqueous solution of BTH (37.5 $\mu \mathrm{g}$ of active ingredient [a.i.] ml $\left.{ }^{-1} ; 178 \mu \mathrm{M}\right)$ (Syngenta Crop Protection Canada, Inc., Guelph) containing $0.01 \%$, vol/vol, Tween 20 . This concentration is similar to that previously found to be effective in Arabidopsis (20). Control plants were either sprayed with water containing Tween 20 or received no treatment.

Pathogen inoculations for SAR against $P$. syringae and bacterial quantification. $P$. syringae pv. maculicola strains were grown at $30^{\circ} \mathrm{C}$ in yeast-tryptone (2YT) medium (29) for $16 \mathrm{~h}$, pelletted in a Sorvall RCA5C centrifuge with GSA rotor (Thermo Fisher Scientific Inc., Waltham, MA) at 5,000 rpm for $15 \mathrm{~min}$ and resuspended in $10 \mathrm{mM} \mathrm{MgCl}$. Bacterial titer was estimated by optical density at $600 \mathrm{~nm}$, with an $\mathrm{OD}_{600}$ of 1 equivalent to $1 \times$ $10^{8}$ colony forming units (CFU) $\mathrm{ml}^{-1}$, and diluted to the desired concentrations with $10 \mathrm{mM} \mathrm{MgCl}_{2}$. Throughout this study, avirulent $P$. syringae pv. maculicola $1120 \mathrm{~B}$ was used at $1 \times$ $10^{6} \mathrm{CFU} \mathrm{ml}^{-1}$ while virulent $P$. syringae pv. maculicola $1848 \mathrm{~B}$ was used at $1 \times 10^{5} \mathrm{CFU} \mathrm{ml}^{-1}$.

To assess the longevity of SAR, either the cotyledons (for the week 3 time point) or the first and second true leaves (all other time points) were infiltrated with avirulent $P$. syringae pv. maculicola $1120 \mathrm{~B}$, from the abaxial side, with a 1-ml plastic syringe. Control plants were either infiltrated with $10 \mathrm{mM} \mathrm{MgCl}_{2}$ alone or received no pretreatment. Secondary inoculations on third and fourth true leaves were done on 4-week-old plants by infiltrating with virulent $P$. syringae pv. maculicola $1848 \mathrm{~B}$. Three days later, eight leaf discs (4-mm diameter) per plant were collected randomly from third and fourth leaves. Leaf samples were ground in $500 \mu \mathrm{l}$ of $10 \mathrm{mM} \mathrm{MgCl}$, serially diluted, and spread on Pseudomonas Agar-F medium (Difco, Sparks, MD) plates. These were incubated at $30^{\circ} \mathrm{C}$ for 3 days before recording the number of colonies. Each time point represents nine samples, with each sample consisting of eight leaf discs.

To monitor the growth of virulent $P$. syringae pv. maculicola $1848 \mathrm{~B}$ at different times following its infiltration into third and fourth leaves, samples (leaf discs) were randomly collected from 4-week-old plants daily, from 1 to 5 days following infiltration, and processed as described above. The effect of SAR was assessed by first infiltrating the first and second leaves of the above plants with $P$. syringae pv. maculicola $1120 \mathrm{~B}$ or $10 \mathrm{mM}$
$\mathrm{MgCl}_{2}$, or by spraying entire plants with $\mathrm{BTH}, 4$ days prior to the secondary infiltration with $P$. syringae pv. maculicola $1848 \mathrm{~B}$.

For comparison of SAR between untransformed and $N a h G$ plants, secondary inoculations were done 4 days after BTH treatment or primary inoculation with avirulent $P$. syringae pv. maculicola $1120 \mathrm{~B}$, and growth of virulent $P$. syringae pv. maculicola was quantified 3 days following the secondary inoculations.

For all $P$. syringae pv. maculicola disease tests, the average number of CFU per leaf disc was analyzed statistically using an unpaired Student's $t$ test at $P=0.05$ (36). A statistically significant reduction in bacterial titer was interpreted as an increase in disease resistance, and accordingly, effective deployment of SAR. All experiments were repeated at least twice.

Pathogen inoculation for SAR against $L$. maculans and disease assessment. L. maculans GL-11, containing the E. coli GUS gene, was grown in black light $(300-400 \mathrm{~nm})$ at $24^{\circ} \mathrm{C}$ on solid V8-juice agar medium (20\% vol/vol V8 juice, $0.75 \%$ $\mathrm{CaCO}_{3}, 1.5 \%$ agar, $100 \mu \mathrm{g} \mathrm{ml}^{-1}$ streptomycin, $50 \mu \mathrm{g} \mathrm{ml}^{-1}$ hygromycin, and $40 \mu \mathrm{g} \mathrm{ml}^{-1}$ rose Bengal). Pycnidiospore suspensions were prepared according to Mahuku et al. (23) to a final concentration of $1 \times 10^{7}$ spores $\mathrm{ml}^{-1}$ in water and stored at $-80^{\circ} \mathrm{C}$.

Ten-day-old cotyledons were used for testing SAR against L. maculans. Primary inoculations were done on one of the cotyledons by infiltrating with avirulent $P$. syringae pv. maculicola $1120 \mathrm{~B}$ on the abaxial side at a concentration of $1 \times 10^{6} \mathrm{CFU}$ $\mathrm{ml}^{-1}$. For controls, cotyledons were infiltrated with $10 \mathrm{mM} \mathrm{MgCl}_{2}$ alone. Secondary inoculations were done on cotyledons from seedlings pretreated with BTH or preinoculated with avirulent $P$. syringae pv. maculicola $1120 \mathrm{~B}$ by placing $10 \mu \mathrm{l}$ of $1 \times 10^{7}$ spore $\mathrm{ml}^{-1}$ L. maculans suspension onto a wound in their center made using a pair of Allegiance tissue teeth forceps (VWR Intl., Mississauga, ON, Canada; cat. no. 25601-080). The seedlings were misted for the first 2 days (95\% relative humidity) and after 6 more days, they were harvested, frozen in liquid nitrogen, and stored at $-80^{\circ} \mathrm{C}$.

Histological and fluorometric GUS assays were performed according to Jefferson et al. (16) using 5-bromo-4-chloro-3-indolyl$\beta$-D-glucuronic acid cyclohexyl ammonium salt (X-Gluc) and 4-methylumbelliferone $\beta$-D-galactopyranoside (MUG) as substrates, respectively. Protein concentration was quantified by the Bradford assay according to the manufacturer's instructions (BioRad, Hercules, CA) using bovine serum albumin as a standard. Fluorometric GUS assay results are presented as pmol methylumbelliferone $\mu \mathrm{g}$ protein ${ }^{-1} \mathrm{~min}^{-1}$. Trypan blue staining of NahG cotyledons was performed as previously described (22) except that samples were cleared with $70 \%$ ethanol. Sections were mounted on a slide and photographed using an Optronics International DEI 750 digital microscope camera (Chelmsford, MA). All experiments were repeated at least twice.

Salicylic acid analysis (adapted from Verberne et al. [34]). Leaf material $(\approx 300 \mathrm{mg}$ ) was ground in liquid nitrogen and placed into a $15-\mathrm{ml}$ round bottom glass culture tube containing $3 \mathrm{ml}$ of extraction solvent $(90 \%$ methanol, $9 \%$ water, $1 \%$ glacial acetic acid) and $200 \mathrm{ng}$ of internal standard (3, 4, 5, 6-tetradeuterosalicylic acid, CDN Isotopes Inc., Pointe-Claire, Québec).

After sonication for $5 \mathrm{~min}$ at $30^{\circ} \mathrm{C}$ in a sonicating water bath, the material was centrifuged for $5 \mathrm{~min}$ at $2,000 \mathrm{rpm}$ at $10^{\circ} \mathrm{C}$. The supernatant was removed and the pellet extracted with another $3 \mathrm{ml}$ of extraction solvent. After centrifugation the pellet was extracted again, this time with $2 \mathrm{ml}$ of methanol. The supernatants were pooled and then the methanol was evaporated under a stream of nitrogen. The remaining aqueous solution was placed on ice, and its $\mathrm{pH}$ adjusted to 10 with $0.1 \mathrm{~N} \mathrm{NaOH}$. The mixture was then extracted with $3 \mathrm{ml}$ of dichloromethane. The aqueous layer was transferred to a new tube and the dichloromethane layer was back-extracted with $2 \mathrm{ml}$ of $0.1 \mathrm{~N} \mathrm{NaOH}$. The pooled aqueous layers were acidified with $5 \% \mathrm{HCl}$ and extracted 3 times with a $1-\mathrm{ml}$ mixture of ethylacetate:cyclohexane $(1: 1, \mathrm{vol} / \mathrm{vol})$. 
The solvents were removed under a stream of nitrogen and the residue was dissolved in $10 \mu \mathrm{l}$ of derivitizing reagent (1:1 mixture of N,O-bis(trimethylsilyl) acetamide and pyridine).

Gas chromatography/mass spectrometry (GC/MS) analysis was accomplished using an Agilent 6890 GC equipped with an auto injector split 30:1 onto a DB-5MS column $(30 \mathrm{M} \times 0.25 \mathrm{~mm}$ i.d., $\mathrm{J} \& \mathrm{~W}$ Scientific, Folsom, CA) that was temperature-programmed to ramp from $175^{\circ} \mathrm{C}$ to $300^{\circ} \mathrm{C}$ at $5^{\circ} \mathrm{C} \min ^{-1}$ (8). The column was connected to an Agilent 5973 mass selective detector. For maximum sensitivity the detector was run under standard conditions with a limited scan range of 265 to $275 \mathrm{~m} / \mathrm{z}$ that gave 37.9 scans per second. For maximum selectivity and accurate quantitation, ions specific to the compounds of interest were monitored and integrated. For the trimethylsilyl derivative of SA $267 \mathrm{~m} / \mathrm{z}$ was used, and for the tetradeutero internal standard, $271 \mathrm{~m} / \mathrm{z}$ was used. The detection limit of the TMS derivative under these conditions was $\approx 0.1 \mathrm{ng}^{-1} \mathrm{l}^{-1}$ and the responses were linear within the concentration range used.

Northern blot analysis. Methods for total RNA isolation and northern analysis were as described by Liu et al. (22). Total RNA from B. napus plants was isolated from frozen samples using Trizol reagent (Invitrogen Life Technologies, Carlsbad). Five micrograms of RNA was denatured and separated on a $1.2 \%$ (wt/vol) agarose $3 \%$ ( $\mathrm{vol} / \mathrm{vol}$ ) formaldehyde gel, photographed under UV light to record amounts loaded, and blotted to nylon membrane (GeneScreen Plus Hybridization Transfer Membrane; NEN Life Sciences Products, Inc., Boston). Membranes were cross-linked with UV light, hybridized at $65^{\circ} \mathrm{C}$ in QuickHyb solution (Stratagene, La Jolla, CA) with probes radiolabelled with $\left(\alpha-{ }^{32} \mathrm{P}\right) \mathrm{dCTP}$ using random primers (Invitrogen, Burlington, Ontario). Two hours after hybridization, membranes were washed twice at room temperature in $2 \times$ SSC $1 \%$ SDS for $15 \mathrm{~min}$; once in $0.1 \times$ SSC and $0.1 \% \mathrm{SDS}$ at $65^{\circ} \mathrm{C}$ for $30 \mathrm{~min}$; and later exposed onto $\mathrm{X}$ ray film (Sterlin Diagnostics, Newark, DE) at $-80^{\circ} \mathrm{C}$. For rehybridization with different gene probes, membranes were stripped by boiling for $30 \mathrm{~min}$ in $0.1 \times \mathrm{SSC}$ and $0.1 \%$ SDS. Hybridization probes contained the entire coding regions of Brassica PR-1 (U70666, herein referred to as $B n P R-1)$ and $P R-2$ (X77990, BnPR-2) genes previously shown to be induced following pathogen challenge $(10,26)$ and BTH (14). Because we were not aware of any

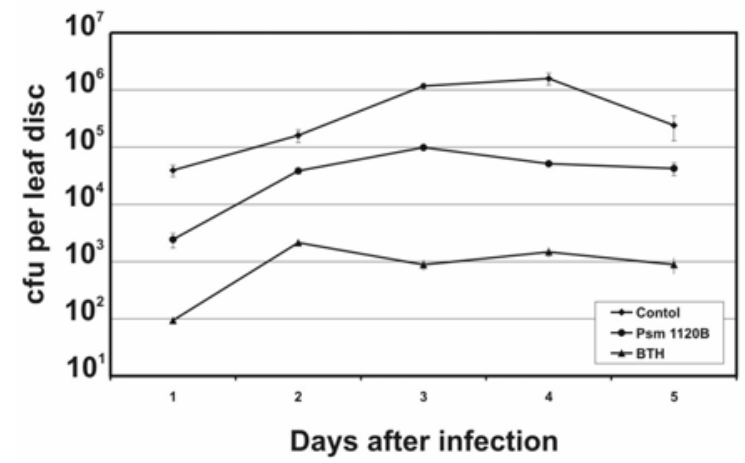

Fig. 1. In planta quantification of the growth of the virulent strain of Pseudomonas syringae pv. maculicola $1848 \mathrm{~B}$ in Brassica napus leaves at different times following systemic acquired resistance (SAR)-inducing pretreatments. Control plants did not receive any pretreatment. SAR treatments consisted of preinoculation with avirulent $P$. syringae pv. maculicola $1120 \mathrm{~B}\left(1 \times 10^{6} \mathrm{CFU}\right.$ $\mathrm{ml}^{-1}$ ) or spraying plants with benzo-(1,2,3)-thiadiazole-7-carbothioic acid Smethyl ester (BTH) $\left(37.5 \mu \mathrm{g}\right.$ active ingredient $\left.\mathrm{ml}^{-1}\right)$. Secondary inoculations with the virulent $P$. syringae pv. maculicola strain $1848 \mathrm{~B}\left(1 \times 10^{5} \mathrm{CFU} \mathrm{ml}{ }^{-1}\right)$ were performed 4 days after primary treatments. Bacterial counts (CFU per leaf disc) were determined for each treatment at the indicated times after secondary inoculation. Each sample consisted of eight leaf discs and every data point represents the mean \pm SE of nine samples. At every time point, values for the $P$. syringae pv. maculicola $1120 \mathrm{~B}$ and $\mathrm{BTH}$ treatments are statistically different from the corresponding values from the control (no SAR) leaves $(P \leq 0.05$, Student's $t$ test). characterized Brassica PR-5-related genes expressed under these conditions, we chose a gene originally isolated from flower buds for analysis, U71244 (4). Coding regions were isolated by reverse transcriptase polymerase chain reaction amplification of mRNA isolated from B. napus seedlings treated with $2 \mathrm{mM} \mathrm{SA}$ (Sigma, St. Louis, MO) for $18 \mathrm{~h}$ using the following oligonucleotide primers: BnPR-1 (5'-ATGAAAGTCACTAACTGTTCTCGAC-3' and $5^{\prime}$-GCCAGTAAACTAGGTAACGGATAA-3'); BnPR-2 (5'-GTGTTAGCATCATCACCAATGTTGCTG-3' and 5'-GGAGATTAGTTAAACTTAACACCATATTTAAGCTG-3'); BnPR-5 (5'CAATGGCTTCACGAAACCTCTTCAACTTCG-3' and $5^{\prime}$-GTGATTTTAACGGCGATGGTGAGGGCAAAA- $3^{\prime}$ ). Isolated fragments were ligated into pTOPO4 cloning vector (Stratagene) and verified by sequencing.

\section{RESULTS}

SAR is effective at reducing disease caused by $P$. syringae pv. maculicola. In Arabidopsis, SAR against $P$. syringae is very effective and has been characterized extensively $(2,3,33)$. Accordingly, we initiated our studies of SAR in B. napus using this bacterial pathogen. As a first step, a collection of $P$. syringae pv. maculicola strains were infiltrated into leaves of B. napus (cv. Westar) to identify those capable of inducing disease symptoms, which could be used to monitor the effectiveness of SAR treatments. At the same time, strains were assessed for their capacity to elicit an HR, and thus having the potential to trigger SAR. One representative strain capable of inducing disease symptoms (P. syringae pv. maculicola 1848B) and one capable of eliciting an HR response ( $P$. syringae pv. maculicola $1120 \mathrm{~B}$ ) were chosen for further study.

The effectiveness of preinoculation with an avirulent (necrogenic) pathogen at reducing disease was tested by infiltrating the first and second true leaves of plants with $1 \times 10^{6} \mathrm{CFU} \mathrm{ml}{ }^{-1}$ of $P$. syringae pv. maculicola $1120 \mathrm{~B}$ and subsequently infiltrating the third and fourth leaves with $1 \times 10^{5} \mathrm{CFU} \mathrm{ml}^{-1}$ of virulent $P$. syringae pv. maculicola $1848 \mathrm{~B}$. Leaves infiltrated with avirulent $P$. syringae pv. maculicola $1120 \mathrm{~B}$ are herein referred to as local leaves, while the third and fourth leaves from these plants are referred to as systemic leaves. To assess the effectiveness of BTH at reducing disease, a separate group of plants was sprayed with $37.5 \mu \mathrm{g}$ a.i. $\mathrm{ml}^{-1}$ BTH prior to infiltration with $P$. syringae pv. maculicola 1848B. These plants were grown in parallel and under the same conditions as those infiltrated with avirulent $P$. syringae pv. maculicola $1120 \mathrm{~B}$, and $\mathrm{BTH}$ treatments were scheduled to coincide with preinoculation treatments. Disease was assessed by visually monitoring symptoms and quantifying viable bacteria in the third and fourth leaves. Preliminary experiments indicated that preinoculation with $10 \mathrm{mM} \mathrm{MgCl}$ or spraying with a Tween 20 solution had no significant effect on growth of P. syringae pv. maculicola 1848 B (data not shown). Accordingly, control plants in most experiments did not receive any pretreatments. Preliminary trials suggested that reduction of disease symptoms was greatest when $P$. syringae pv. maculicola $1848 \mathrm{~B}$ was inoculated 4 days after primary treatments. Therefore, these conditions were selected to quantify bacterial growth at different times following infiltration with $P$. syringae pv. maculicola 1848B.

In leaves from control plants, bacteria multiplied to $4 \times 10^{4} \mathrm{CFU}$ per leaf disc after one day and increased to $1.6 \times 10^{6} \mathrm{CFU}$ per leaf disc after 4 days before tapering off (Fig. 1). Leaves from plants that had been preinoculated with the avirulent pathogen displayed a 4.1- (day 2 and day 5) to 31-fold (day 4) reduction in the titer of virulent $P$. syringae pv. maculicola $1848 \mathrm{~B}$, compared to control plants that received no pretreatments sampled at the same time. Leaves from plants treated with BTH showed a dramatic reduction of $P$. syringae pv. maculicola $1848 \mathrm{~B}$ growth (75- to 1,328 fold) when compared to control plants. Statistical analysis using 
Student's $t$ test at $P \leq 0.05$ indicated that, in both the SAR treatments, bacterial titers measured at every time point were significantly lower than those from control leaves at the corresponding time. Extracts from leaves infiltrated with buffer alone did not yield any colonies at the dilutions used for the infected plants. Preinoculation with the avirulent pathogen resulted in a marked reduction of visible disease symptoms in leaves subsequently infiltrated with virulent bacteria, while plants treated with BTH displayed no disease symptoms following infiltration with the virulent bacteria (data not shown).

SAR against $P$. syringae pv. maculicola is long lasting. To determine the longevity of SAR, bacterial titers were quantified in systemic leaves infected with virulent $P$. syringae pv. maculicola $1848 \mathrm{~B}$ at various times after pretreatment with avirulent P. syringae pv. maculicola $1120 \mathrm{~B}$ or BTH. In order to make comparisons between treatments more meaningful, the secondary inoculations were all performed at the same time, on plants of the same age, with the pretreatments having been performed at different times. As shown in Figure 2A, preinoculation with avirulent $P$. syringae pv. maculicola $1120 \mathrm{~B}$ resulted in a 14 - to 19 -fold reduction in bacterial growth. Values from all of the time points were statistically different from those obtained in the control plants $(P \leq 0.05)$, indicating that preinoculation with avirulent $P$. syringae pv. maculicola $1120 \mathrm{~B}$ can effectively increase disease resistance even when the secondary inoculation was performed 3 weeks after the pretreatment, the longest time difference tested in this study.

Treatment with BTH resulted in a 95- to 1,077-fold reduction in bacterial growth, with the maximum reduction observed when the secondary inoculation was performed 4 to 7 days after the primary treatment (Fig. 2A). All values measured in leaves treated with BTH were statistically lower than the control $(P \leq 0.05)$. These results indicate that both SAR treatments tested provide long lasting protection against virulent $P$. syringae pv. maculicola in $B$. napus and confirm the data presented in Figure 1 that treatment with BTH is more effective than preinoculation with the avirulent pathogen $P$. syringae pv. maculicola $1120 \mathrm{~B}$ under the experimental conditions used.

SAR against $P$. syringae pv. maculicola is correlated with the accumulation of PR gene transcripts. Changes in PR gene expression associated with SAR induction were analyzed by northern blot hybridization in leaf samples collected at various times following pretreatments (Fig. 2B). In local leaves inoculated with avirulent $P$. syringae pv. maculicola $1120 \mathrm{~B}$, high levels of $B n P R-1$ and $B n P R-2$ mRNA were already detected 1 day postinfection (Fig. 2B), the shortest time interval used between primary and secondary inoculations in this study. Sampling of earlier time intervals detected very low levels of $B n P R-1$ in local leaves after 1 and $4 \mathrm{~h}$, and high levels by $8 \mathrm{~h}$ (Fig. 2C). Steadystate levels of PR gene mRNA increased slightly during the first week before starting to decline at day 14 (Fig. 2B). In systemic leaves, levels of the above gene transcripts were initially substantially lower than observed in the local leaves and gradually increased until day 7 (Fig. 2B and C). Levels then remained relatively constant and similar to those detected in infected leaves for the remainder of the experiment. Treatment with BTH induced $B n P R-1$ and $B n P R-2$ transcript accumulation to levels comparable to the highest levels observed in local leaves (Fig. 2B). Expression of BnPR-5 was not detected in any of the tissues analyzed, while transcripts from none of the PR genes analyzed were detected in leaves from untreated plants at any of the developmental stages considered (Fig. 2B).

PR transcripts were also monitored in leaves at different times following infection with the virulent $P$. syringae pv. maculicola strain 1848B (Fig. 2D). In plants that had not received SAR pretreatments, infection with $P$. syringae pv. maculicola $1848 \mathrm{~B}$ was sufficient to induce $B n P R-1$ and $B n P R-2$ expression as early as 1 day postinfection. In plants where first and second leaves had
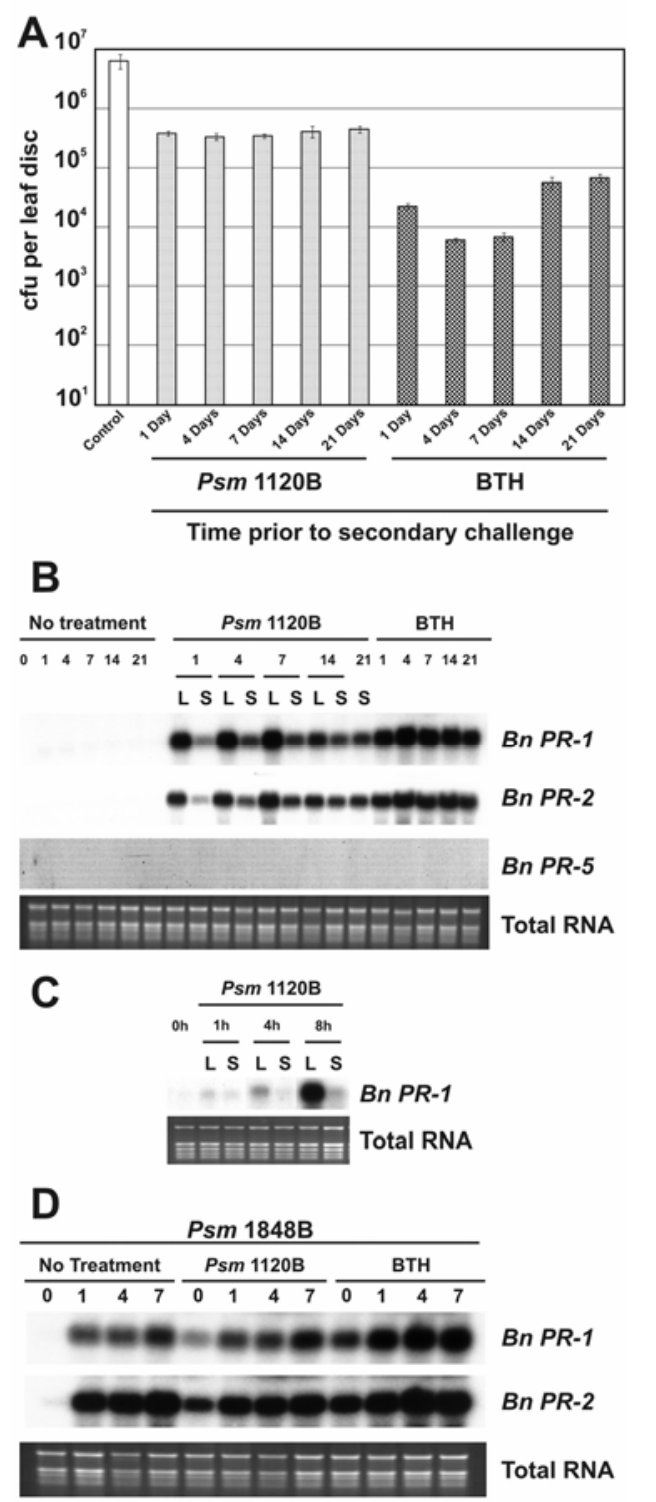

Fig. 2. Systemic acquired resistance (SAR) response and $B n P R$ gene transcript accumulation in wild-type Brassica napus plants, induced by Pseudomonas syringae pv. maculicola $1120 \mathrm{~B}$ or benzo-(1,2,3)-thiadiazole-7-carbothioic acid S-methyl ester (BTH). A, Plants were either preinoculated with a $1 \times$ $10^{6} \mathrm{CFU} \mathrm{ml} \mathrm{m}^{-1}$ suspension of avirulent $P$. syringae pv. maculicola $1120 \mathrm{~B}$ or sprayed with $37.5 \mu \mathrm{g}$ active ingredient $\mathrm{ml}^{-1} \mathrm{BTH}$ for the amount of time indicated before a secondary challenge inoculation with the virulent P. syringae pv. maculicola strain $1848 \mathrm{~B}\left(1 \times 10^{5} \mathrm{CFU} \mathrm{ml}^{-1}\right)$. Control plants did not receive any pretreatments. Three days later, eight leaf discs per sample were collected and bacterial titers quantified. Each data point represents the mean \pm SE of nine samples. At every time point, values for preinoculation and BTH treatments are statistically significant from the control $(P \leq 0.05$, Student's $t$ test). B, Northern blot analyses of $B n P R-1, B n P R-2$, and $B n P R-5$ transcript accumulation at different times (in days) following the SARinducing pretreatments described in $\mathrm{A} . \mathrm{L}=$ local, infected leaf; $\mathrm{S}=$ systemic, noninfected leaf. $\mathbf{C}$, Northern blot analyses of $B n P R-1$ transcript accumulation in local leaves at early stages following challenge inoculation with the avirulent $P$. syringae pv. maculicola strain $1120 \mathrm{~B}\left(1 \times 10^{6} \mathrm{CFU} \mathrm{ml^{-1 }}\right)$. D, Northern blot analyses of $B n P R-1$ and $B n P R-2$ accumulation in systemic leaves at different times (in days) following challenge inoculation with the virulent $P$. syringae pv. maculicola strain $1848 \mathrm{~B}\left(1 \times 10^{5} \mathrm{CFU} \mathrm{ml}^{-1}\right)$. Plants had received SAR-inducing pretreatments 4 days previously, as described in A. B, C, and D, Five micrograms of total RNA was loaded for each sample and hybridized with radioactive labeled DNA probes. The same filters were used for $B n P R-1, B n P R-2$, and $B n P R-5$. These were stripped of hybridizing DNA between each round of hybridization. Photos of ethidium bromidestained gels are included as a measure of RNA loading. 
been inoculated 4 days previously with avirulent $P$. syringae pv. maculicola $1120 \mathrm{~B}$, systemic leaves infected with $P$. syringae pv. maculicola 1848B expressed slightly higher levels of BnPR-1 transcripts than observed in plants that did not receive the pretreatment, but appeared to have similar levels of $B n P R-2$, except at day 0 , when $B n P R-1$ and $B n P R-2$ transcripts were detected only in systemic leaves from plants previously inoculated with the avirulent bacterium. Transcript levels of both of these PR genes were higher in BTH-treated plants than those receiving no pretreatment or preinoculated with $P$. syringae pv. maculicola 1120B. Expression of BnPR-5 was not detected in any of the leaves infected with $P$. syringae pv. maculicola $1848 \mathrm{~B}$ (data not shown). Together, these results indicate that SAR against $P$. syringae pv. maculicola in mature B. napus plants is associated

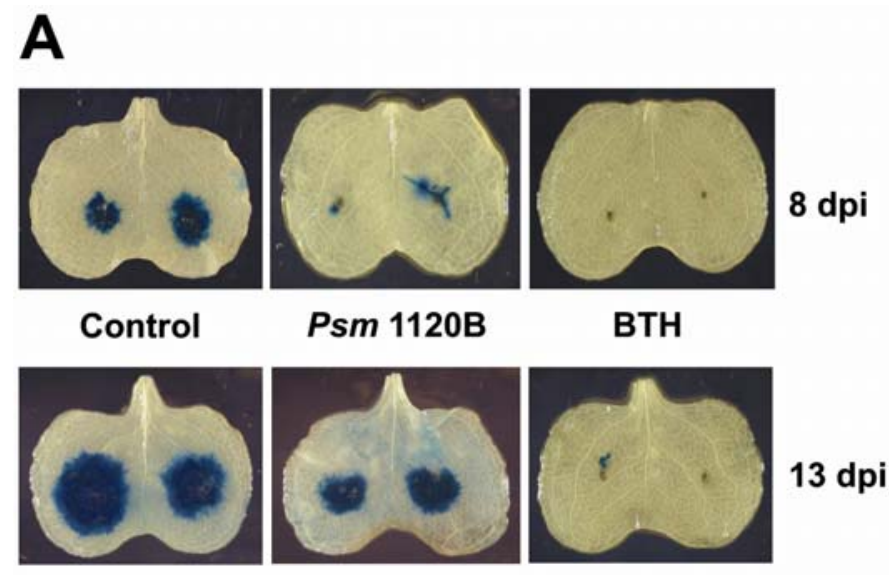

B

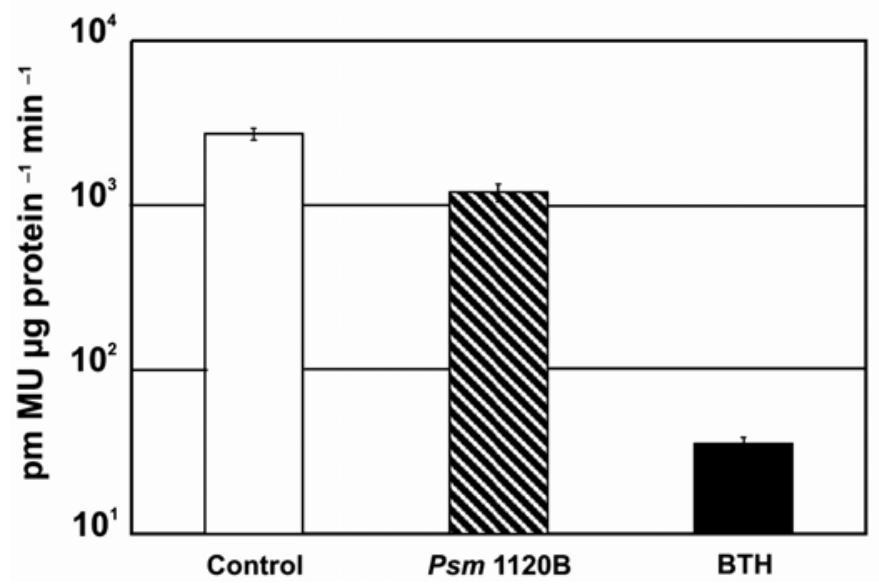

Fig. 3. Effectiveness of systemic acquired resistance-inducing pretreatments in wild-type Brassica napus cotyledons against Leptosphaeria maculans. Sixday-old B. napus seedlings were either sprayed with water (control), preinoculated with $1 \times 10^{6} \mathrm{CFU} \mathrm{ml}^{-1}$ of avirulent Pseudomonas syringae pv. maculicola $1120 \mathrm{~B}$, or sprayed with $37.5 \mu \mathrm{g}$ active ingredient $\mathrm{ml}^{-1}$ benzo(1,2,3)-thiadiazole-7-carbothioic acid S-methyl ester (BTH). Four days later, $10-\mu \mathrm{l}$ drops of $L$. maculans spores $\left(1 \times 10^{7} \mathrm{CFU} \mathrm{\textrm {ml } ^ { - 1 } )}\right.$ were placed on cotyledons and incubated for 8 or 13 days. Different cotyledons from the same seedlings received the primary and secondary inoculations. A, Histological staining of $L$. maculans fungal hyphae for Escherichia coli $\beta$-Dglucuronidase $(G U S)$ gene expression using X-Gluc. Hyphal growth 8 or 13 dpi (days post inoculation) of the fungus is indicated by blue coloration; $\mathbf{B}$, Quantitative GUS expression analyses in 8-dpi cotyledons using 4-methylumbelliferone $\beta$-D-galactopyranoside (MUG) as substrate. Reduction in growth of L. maculans is indicated by decreased GUS expression. Each bar represents the mean \pm SE of six samples. GUS activity measured in cotyledons from seedling preinoculated with $P$. syringae pv. maculicola 1120B or sprayed with BTH were statistically lower than control values $(P \leq$ 0.05 , Student's $t$ test). with the induction of PR genes at both the induction and manifestation stages, and that there is a positive relationship between the effectiveness of SAR and the steady-state level of PR transcripts.

SAR is effective against $L$. maculans. Studies have shown that early infections of $L$. maculans cause the greatest damage, with infections before the six-leaf stage causing severe yield losses (15). Stems are most susceptible to infection when the plants are in cotyledon or one- to two-leaf stage. Therefore, we tested the effectiveness of SAR against L. maculans in B. napus plants at the cotyledon stage.

To trigger SAR, either one cotyledon from 10-day-old seedlings was infiltrated with avirulent $P$. syringae pv. maculicola 1120B $\left(1 \times 10^{6} \mathrm{CFU} \mathrm{ml}{ }^{-1}\right)$ or the seedling was sprayed with $37.5 \mu \mathrm{g}$ a.i. $\mathrm{ml}^{-1}$ BTH. Four days later, two 10- $\mu$ drops of L. maculans spore suspension $\left(1 \times 10^{7} \mathrm{ml}^{-1}\right)$ were placed on the cotyledons. In cases where one cotyledon had been preinoculated with avirulent $P$. syringae pv. maculicola $1120 \mathrm{~B}$, the secondary infection with L. maculans was performed on the other cotyledon. The L. maculans strain used in this study (GL-11) expressed the GUS gene. Accordingly, qualitative and quantitative analysis of GUS activity was exploited as a measure of fungal growth.

Histological staining for GUS activity 8 and 13 days after L. maculans infection revealed that preinoculation of one of the cotyledons with avirulent $P$. syringae pv. maculicola $1120 \mathrm{~B}$ substantially decreased the area of fungal growth (Fig. 3A). This reduction was even more dramatic in cotyledons from seedlings treated with BTH. Quantitatively, GUS activity was reduced by 2.3 -fold in seedlings preinoculated with avirulent $P$. syringae pv. maculicola 1120B and 77-fold following treatment with BTH (Fig. 3B). These differences were statistically significant $(P \leq$ 0.05 ) and indicate that SAR induced at the cotyledon stage of $B$. napus plants is effective against $L$. maculans.

$B n P R-1$ and BnPR-2 transcripts accumulated at high levels in cotyledons infected with avirulent $P$. syringae pv. maculicola 1120B and following BTH treatment (Fig. 4A). Expression of PR genes was much lower in the systemic cotyledons that were not infected with L. maculans. In the absence of pretreatment, infection with $L$. maculans resulted in the accumulation of low levels of BnPR-1 and BnPR-2 mRNA (Fig. 4B). Preinoculation with avirulent $P$. syringae pv. maculicola $1120 \mathrm{~B}$ resulted in higher levels of PR gene transcripts in cotyledons infected with $L$. maculans, while spraying with BTH induced the highest levels of PR gene mRNA in these tissues. Thus, as observed in mature plants infected with virulent $P$. syringae pv. maculicola $1848 \mathrm{~B}$, there is a positive relationship between the effectiveness of SAR against L. maculans and the expression of $\mathrm{PR}$ genes in B. napus seedlings.

Systemic acquired resistance is compromised in NahG B. napus plants. The requirement of SA for SAR in B. napus was tested in transgenic plants expressing the bacterial salicylate hydroxylase gene ( $N a h G$; Fig. 5A) that converts SA to catechol (11). To confirm the efficacy of the NahG transgene, levels of free SA were measured in local and systemic leaves of plants 4 days after preinoculation with avirulent $P$. syringae pv. maculicola 1120B. As shown in Figure 5B, inoculation of untransformed (wild-type) plants with avirulent $P$. syringae pv. maculicola $1120 \mathrm{~B}$ resulted in a 28 -fold increase in SA levels in local tissues and a roughly twofold increase in systemic leaves. In contrast, the $N a h G$ plants did not show any substantial increase in free SA levels in either locally infected or systemic leaves (Fig. 5B).

In the absence of SAR inductive pretreatments, bacterial titers measured in leaves of $N a h G$ plants infected with virulent P. syringae pv. maculicola $1848 \mathrm{~B}$ were twofold higher than those measured in untransformed plants (Fig. 5C). This difference was statistically significant $(P \leq 0.05)$. To determine if SAR could be induced in NahG plants, the third and fourth leaves of untransformed and $N a h G$ plants were infiltrated with the virulent 
P. syringae pv. maculicola 1848B 4 days after preinoculation of first and second leaves with the avirulent $P$. syringae pv. maculicola 1120B, and bacterial growth quantified as described above. Untransformed plants showed a fourfold reduction in the growth of $P$. syringae pv. maculicola $1848 \mathrm{~B}$ whereas the NahG plants did not show any significant decrease (Fig. 5C).

In Arabidopsis and tobacco, loss of SAR observed in NahG plants can be rescued by treatment with BTH $(9,20)$. This chemical is thought to act at the same point as, or downstream of, SA in the signaling pathway leading to $\operatorname{SAR}(9,20)$. To test whether the loss of resistance in NahG B. napus was specifically attributed to interference with SA signaling, plants were treated with BTH and assessed for disease resistance. Following BTH treatment, titers of virulent $P$. syringae pv. maculicola $1848 \mathrm{~B}$ in leaves of $N a h G$ plants were significantly lower (77-fold) than those measured in the absence of pretreatment or following preinoculation with avirulent $P$. syringae $1120 \mathrm{~B}$ (Fig. 5C). These differences were statistically significant $(P \leq 0.05)$. However, titers in $N a h G$ plants treated with BTH continued to be higher than those measured in leaves of untransformed plants treated with BTH.

When compared with untransformed plants, both infected (local) and systemic leaves of $N a h G$ plants displayed substantial

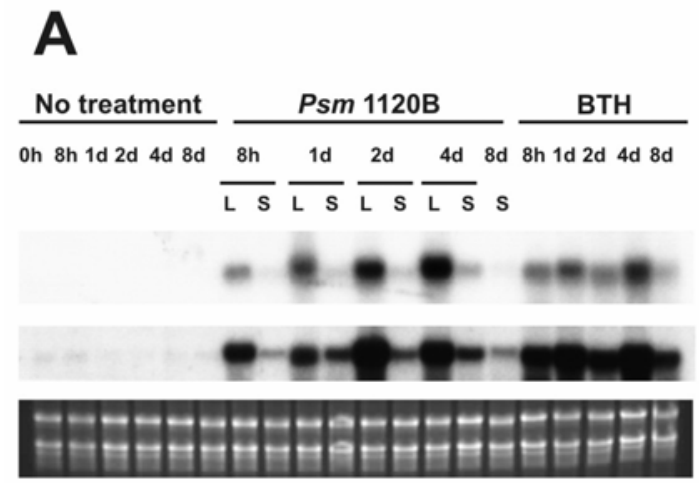

Bn PR-1

Bn PR-2

Total RNA
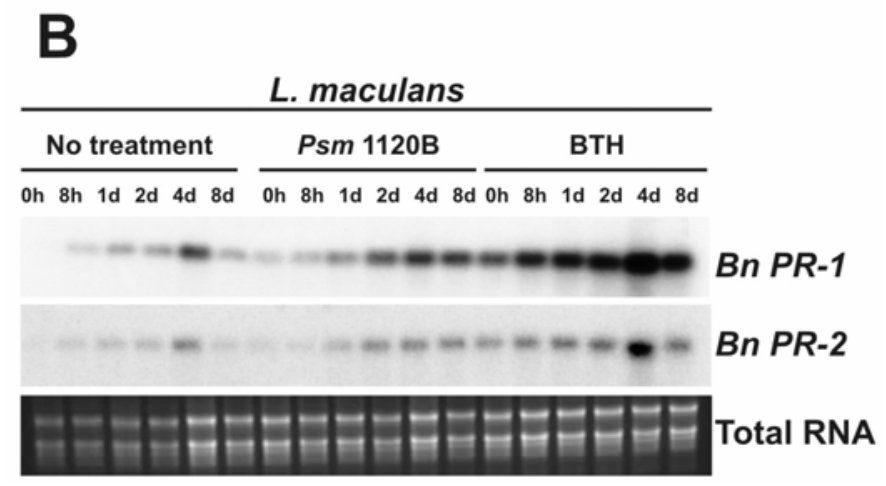

Fig. 4. $B n P R$ transcript accumulation in wild-type Brassica napus cotyledons following systemic acquired resistance-inducing pretreatments. Five micrograms of total RNA was loaded for each sample and hybridized with radioactive labeled DNA probes. The same filters were used for $B n P R-1$ and $B n P R-2$ and stripped of hybridizing DNA between each round of hybridization. Photos of ethidium bromide-stained gels are included as a measure of RNA loading. A, Northern blot analyses of $B n P R-1$ and $B n P R-2$ at different times following pretreatments. P. syringae pv. maculicola $1120 \mathrm{~B}$ indicates preinoculation with avirulent Pseudomonas syringae pv. maculicola 1120B (1 $\left.\times 10^{6} \mathrm{CFU} \mathrm{ml} \mathrm{m}^{-1}\right)$; BTH indicates seedlings were sprayed with $37.5 \mu \mathrm{g}$ active ingredient $\mathrm{ml}^{-1}$ benzo-(1,2,3)-thiadiazole-7-carbothioic acid S-methyl ester. $\mathrm{L}=$ local cotyledon and $\mathrm{S}=$ systemic cotyledon. $\mathbf{B}$, Northern blot analyses of $B n P R-1$ and $B n P R-2$ at different times in cotyledons following challenge inoculation with Leptosphaeria maculans $\left(1 \times 10^{7} \mathrm{CFU} \mathrm{\textrm {ml } ^ { - 1 } )}\right.$ spores. Cotyledons had previously received the pretreatments for 4 days as described in A. Separate cotyledons of the same seedling were used for seedlings that received both bacterial and fungal inoculations.
A
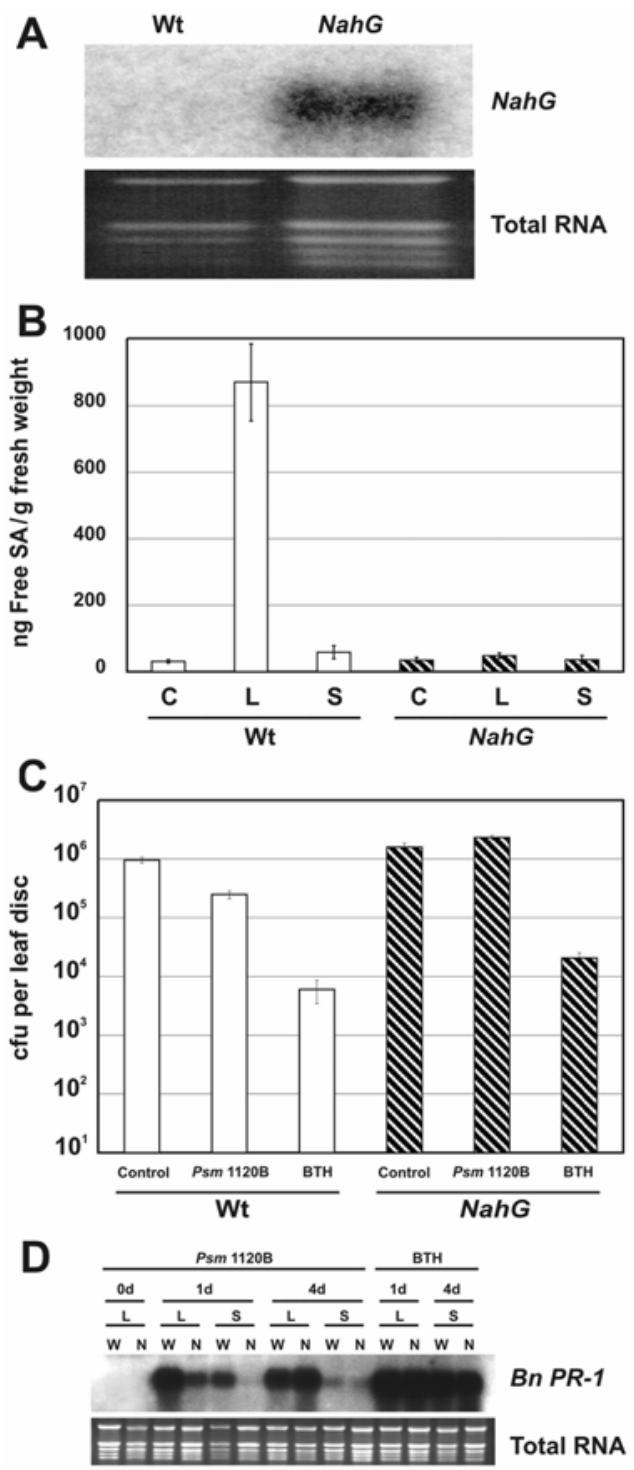

Fig. 5. Systemic acquired resistance (SAR) response against Pseudomonas syringae and BnPR gene expression in NahG Brassica napus plants. A, Northern blot showing expression of the $N a h G$ gene in transgenic B. napus plants. Five micrograms of total RNA was loaded for each sample and probed with radioactive labeled $N a h G$ probe. A photo of the ethidium bromide-stained gel is included as a measure of RNA loading; B, Gas chromatography/mass spectrometry (GC/MS) quantification of free salicylic acid in leaf tissues four days after infiltration with $1 \times 10^{6} \mathrm{CFU} \mathrm{ml}^{-1}$ of avirulent Pseudomonas syringae pv. maculicola $1120 \mathrm{~B} . \mathrm{L}=$ local leaf; $\mathrm{S}=$ uninfected, systemic leaves from plants infiltrated with the avirulent bacteria; and $\mathrm{C}=$ untreated control leaves. Each bar represents the mean \pm SE of three samples. $C$, SAR response in wild-type and $N a h G$ plants. Three-week-old wild-type (open bars) or NahG transgenic (hatched bars) B. napus plants were infiltrated with $10 \mathrm{mM} \mathrm{MgCl}$ (control), preinoculated (first and second leaves) with $1 \times 10^{6} \mathrm{CFU} \mathrm{ml}{ }^{-1}$ of avirulent P. syringae pv. maculicola $1120 \mathrm{~B}$ or sprayed with $37.5 \mu \mathrm{g}$ active ingredient $\mathrm{ml}^{-1}$ benzo-(1,2,3)-thiadiazole-7-carbothioic acid S-methyl ester (BTH). Four days later, the third and fourth leaves of each plant were challenge-inoculated with the virulent $P$. syringae pv. maculicola strain 1848B. Three days after the second inoculation, eight leaf discs were collected randomly from third and fourth leaves and bacterial titers were quantified. Each data point represents the mean $\pm \mathrm{SE}$ of nine samples. All treatments for wild-type and NahG are statistically different from the wild-type $\mathrm{MgCl}_{2}$ control $(P \leq 0.05$, Student's $t$ test). Values for NahG plants preinoculated with $P$. syringae pv. maculicola $1120 \mathrm{~B}$ or sprayed with BTH are also statistically significant from the NahG $\mathrm{MgCl}_{2}$ control; D, Northern blot analyses show BnPR-1 transcript accumulation in wild-type and $N a h G B$. napus plants 0,1 , and 4 days after SAR pretreatment. $\mathrm{C}=$ untreated control; $\mathrm{L}=$ local (first and second) leaf inoculated with $1 \times 10^{6} \mathrm{CFU} \mathrm{ml}{ }^{-1}$ avirulent $P$. syringae pv. maculicola $1120 \mathrm{~B} ; \mathrm{S}=$ systemic (third and fourth) leaves of the same plants; and B = leaf sprayed with $37.5 \mu \mathrm{g}$ active ingredient $\mathrm{ml}^{-1} \mathrm{BTH}$. Five micrograms of total RNA was loaded for each sample and hybridized with radioactive labeled DNA probes. A photo of the ethidium bromide-stained gel is included as a measure of RNA loading. 
reductions of steady-state $B n P R-1$ transcripts 1 day following challenge with avirulent $P$. syringae pv. maculicola 1120B (Fig. 5D). Four days following infection, levels of BnPR-1 mRNA in $N a h G$ plants were similar to those observed in untransformed plants. Treatment of NahG plants with BTH also resulted in the accumulation of relatively high levels of $B n P R-1$ transcripts (Fig. 5D).

The binary T-DNA plasmid used to generate the NahG plants possessed a chimeric selectable marker gene containing GUS (27). Accordingly, we were unable to use this reporter to measure growth of $L$. maculans. Instead, fungal growth was assessed by monitoring mycelial mass using trypan blue staining. Regardless of whether NahG seedlings were preinoculated with avirulent $P$. syringae pv. maculicola $1120 \mathrm{~B}$, the fungus grew to entirely cover the cotyledons (Fig. 6A, bottom row). By comparison, fungal growth was not as extensive on wild-type cotyledons and preinoculation was modestly effective at reducing fungal growth (Fig. 6A, top row). Trypan blue staining of $N a h G$ cotyledons after BTH treatment indicated that growth of L. maculans was significantly reduced when compared with cotyledons that did not receive any pretreatment (Fig. 6A).
When compared with untransformed cotyledons, levels of $B n P R-1$ transcripts were substantially lower in local and systemic cotyledons of $N a h G$ seedlings $8 \mathrm{~h}$ after inoculation with avirulent $P$. syringae pv. maculicola 1120B (Fig. 6B). Levels remained lower in both local and systemic NahG cotyledons 1 and 2 days after inoculation, although the differences between untransformed cotyledons were not as pronounced. Therefore, the loss of SAR observed in the $N a h G$ seedlings, as observed in mature plants (Fig. 5D), is associated with reduced accumulation of BnPR-1 transcript, particularly during the early stages following preinoculation with the avirulent pathogen. Altogether, the analysis of $N a h G$ transgenics indicate that the SA signaling pathway is critical for effective SAR against $P$. syringae and $L$. maculans in B. napus.

\section{DISCUSSION}

We have demonstrated that localized preinoculation with an avirulent pathogen and application of the chemical BTH effectively enhances resistance of B. napus plants to virulent strains of
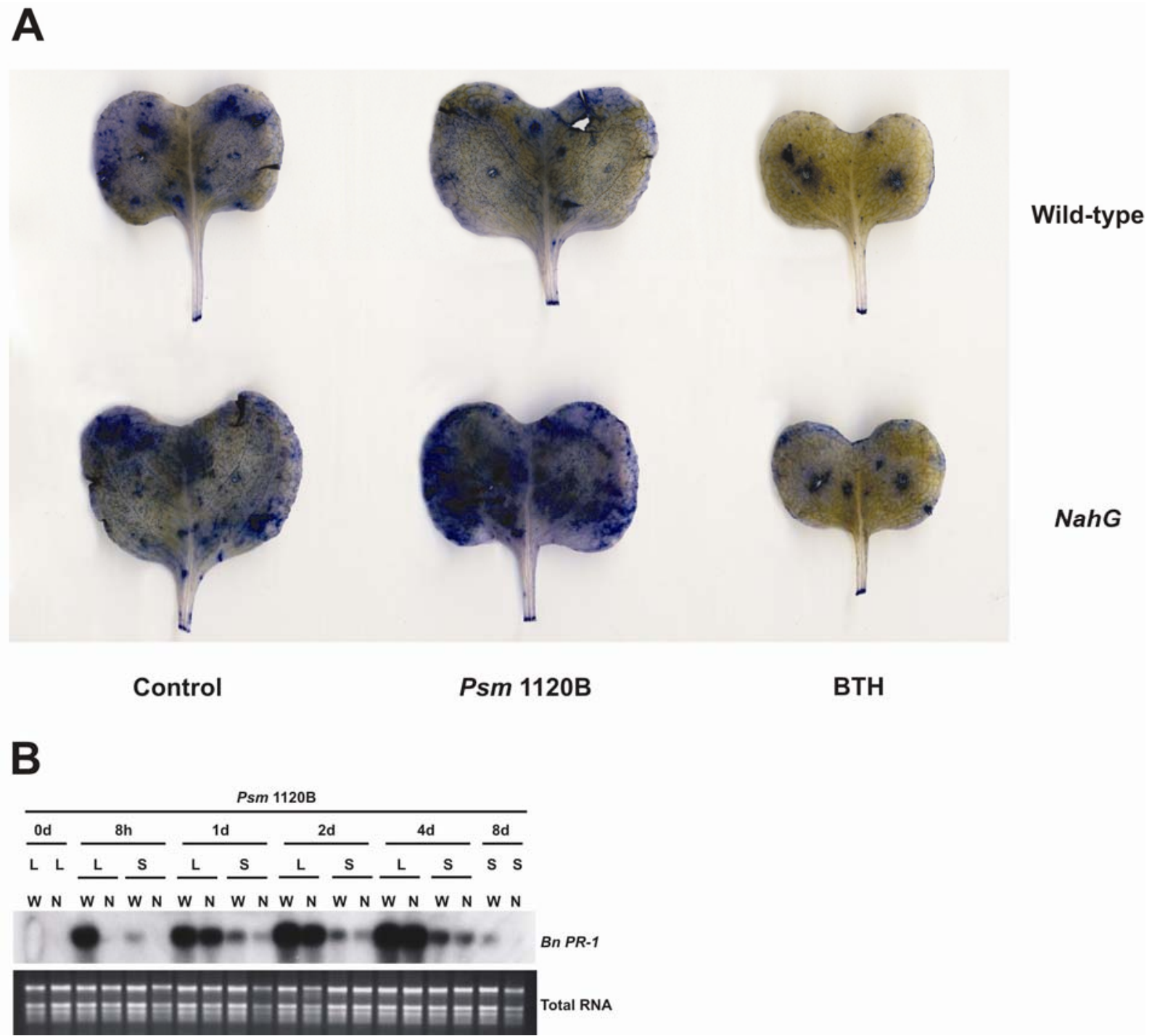

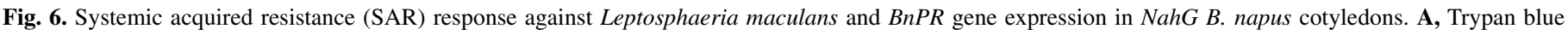

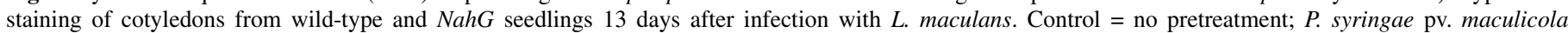

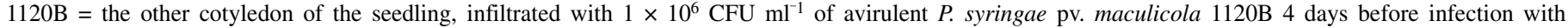

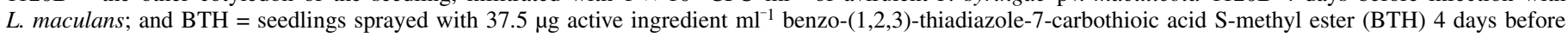

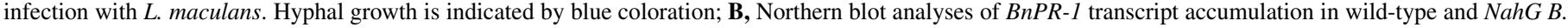

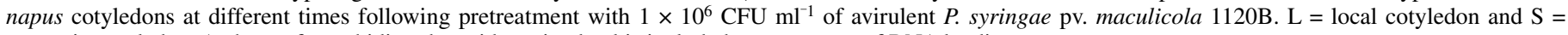
systemic cotyledon. A photo of an ethidium bromide-stained gel is included as a measure of RNA loading. 
the bacterial pathogen $P$. syringae pv. maculicola and the fungal pathogen L. maculans. Importantly, we show that enhanced resistance to both pathogens displays the hallmarks of a typical SAR response, including the accumulation of $\mathrm{PR}$ gene transcripts and a requirement for $\mathrm{SA}$.

Preinoculation with an avirulent pathogen and BTH treatment of $B$. napus plants resulted in the rapid accumulation of $P R-1$ and $P R-2$ transcripts, two genes widely accepted as markers for SAR (28). Comparisons of different treatments indicate that the expression level of these marker genes was associated with the effectiveness of SAR. For example, plants preinoculated with avirulent $P$. syringae pv. maculicola $1120 \mathrm{~B}$ expressed relatively low levels of PR genes in systemic leaves and displayed only moderately higher levels of resistance compared with untreated plants, which did not accumulate detectable levels of PR transcripts prior to secondary infection with virulent pathogens. Plants treated with BTH expressed the highest levels of PR gene mRNA and displayed the most resistance (Figs. 2 to 4 ). In contrast, $N a h G$ plants failed to display SAR in response to inoculation with avirulent $P$. syringae pv. maculicola $1120 \mathrm{~B}$ and accumulated substantially less BnPR- 1 gene transcripts in local and systemic leaves (Fig. 5D) and cotyledons (Fig. 6B). The reduction in $B n P R-1$ levels compared with untransformed (wildtype) plants was particularly evident in the early stages following preinoculation with the avirulent pathogen. This association of $B n P R$ gene transcript accumulation with SAR suggests that the proteins they encode likely contribute to the observed increase in disease resistance.

Hennin et al. (14) reported rapid induction of $P R-1$ and $P R-2$ transcripts in B. napus following treatment with BTH. However, these authors did not correlate PR gene expression with disease resistance. BTH treatment also led to the enhancement of $\beta-1,3-$ glucanase (PR-2) enzymatic activity and protein levels in $\mathrm{B}$. oleracea seedlings, before and after infection with Peronospora parasitica (38). However, whereas our study and that of Hennin et al. (14) clearly observed rapid and dramatic increases in $B n P R-1$ mRNA, Ziadi et al. (38) detected only weak and slow induction of $P R-1$. One possible explanation for this discrepancy is that the $B n P R-1$ cDNA used as a probe encodes a protein distinct from the one recognized by the PR-1 antibody, which was raised against a tobacco isoform. Alternatively, the differences may be attributed to posttranscriptional regulation of PR-1 or to the higher levels of BTH used in the present study and in that of Hennin et al. (14). Ziadi et al. (38) also failed to detect substantial changes in the expression of PR-5 protein, which is consistent with our inability to detect $P R-5$ mRNA following pathogen challenge or during SAR. Together, these results suggest that PR-5 may not be associated with SAR in Brassica species.

Our conclusion that SAR in B. napus requires SA is based on two lines of evidence. First, BTH, a structural analog of SA, was highly effective at enhancing resistance to $P$. syringae pv. maculicola and L. maculans. In other plant species BTH and SA induce the expression of the same set of SAR genes and confer resistance to the same spectrum of pathogens $(9,20)$. Both compounds are thought to activate SAR through the same signaling pathway, possibly by binding to the same receptor(s) (28). Second, blocking the pathogen-induced accumulation of free SA by expression of the $N a h G$ transgene abolished the effectiveness of the localized preinoculation treatment in conferring resistance against subsequent infections by virulent pathogens. NahG B. napus plants continued to mount an effective SAR in response to BTH treatment (Figs. 5C and 6A), indicating that the above effect was largely due to the inability to accumulate SA.

In addition to being unable to mount an effective SAR response, Arabidopsis and tobacco NahG plants have been reported to be severely compromised in basal resistance (5). In contrast, $N a h G$ B. napus plants were only marginally more susceptible to virulent $P$. syringae pv. maculicola in the absence of SAR- inducing pretreatments (Fig. 5C), suggesting that loss of SA preferentially compromises SAR, but not basal resistance, against this pathogen in $B$. napus. Also, the reduction of PR gene transcript levels observed in $B$. napus NahG plants and seedlings was much more pronounced in the early stages following infection with the avirulent pathogen (Figs. 5D and 6B). Analysis by GCMS confirmed the effective block of SA accumulation in B. napus $N a h G$ plants (Fig. 5B). This suggests an important contribution of one or more SA-independent signaling pathways for the lateonset pathogen-induced accumulation of $P R-1$ and $P R-2$ transcripts in this species. Further experimentation will be required to test this hypothesis and define the pathways involved. Nevertheless, the observation that delaying the accumulation of $P R$ genes in $N a h G$ B. napus plants sub-stantially compromised disease resistance is consistent with the notion that the speed at which defense responses are activated is critical in determining the outcome of plant-pathogen interactions (31).

The fact that preinoculation with an avirulent strain of $P$. syringae pv. maculicola, and spraying with $\mathrm{BTH}$, induced the expression of $B n P R-1$ and $B n P R-2$ and conferred resistance to virulent strains of both $P$. syringae pv. maculicola and L. maculans suggests that both these treatments may activate the same signaling pathways in B. napus. This phenomenon was also observed in Arabidopsis, tobacco, and other plant species $(33,35)$. However, the same is not true of the chemical MSB, which induced systemic resistance against $L$. maculans without activation of $B n P R-1$ (1). Despite the possibility that they may induce the same signaling cascades, our results clearly show that preinoculation with an avirulent pathogen and BTH treatment are not equally effective at conferring SAR. Previous reports suggest that SAR requires an induction time of about 2 days to 2 weeks to be fully established (30). Altering the length of time between the preinoculation and the infection with virulent $P$. syringae $\mathrm{pv}$. maculicola did not increase the effectiveness of this pretreatment relative to BTH application (Fig. 2A). Localized infection with a microbe capable of eliciting plant cell necrosis is thought to trigger the production of a systemic SAR signal that is mobilized through the phloem $(7,24)$. The nature of the systemic signal is still unknown, although recent evidence suggests the involvement of a lipid-based molecule $(7,19,24)$. Application of the SA analog INA can rescue SAR in the Arabidopsis defective in induced resistancel mutant, which is unable to produce the systemic signal (24), indicating that treatment with INA, and therefore probably BTH as well, likely bypasses the requirement for the systemic signal. Accordingly, the relatively low level of SAR triggered by preinoculation with the avirulent pathogen, compared to BTH treatment, may indicate that the production, mobilization, or perception of the systemic signal is limiting the effectiveness of localized preinoculation with avirulent pathogens. In addition to altering the time between preinoculation and the infection with virulent $P$. syringae pv. maculicola, we also tested the effect of altering the strain of avirulent bacterium and the area of tissue preinoculated, but neither substantially increased SAR (data not shown). We do not believe that the superior performance of BTH is due to direct growth inhibition of the virulent pathogens, since neither BTH nor its metabolites appear to have antifungal activities (9). Furthermore, localized infiltration of BTH on uninfected leaves was as effective as spraying the entire plant in eliciting SAR (data not shown).

A previous report had demonstrated that pre- or coinfection with a weakly virulent strain of $L$. maculans was effective at inducing SAR against a highly virulent strain in mature $B$. napus plants (23). Our results confirm that preinfection with an avirulent pathogen is effective at inducing SAR against virulent $L$. maculans. Furthermore, they extend previous findings by demonstrating that the enhanced resistance is associated with PR gene induction and requires SA, and that BTH is highly effective at reducing disease caused by L. maculans. Importantly, we show that SAR 
against $L$. maculans is effective at the seedling stage, a time at which disease caused by this fungus can be particularly devastating.

\section{ACKNOWLEDGMENTS}

We thank J. Taylor, Horticulture Research International, Wellesbourne, U.K., for $P$. syringae pv. maculicola strains; G. Séguin Swartz, Agriculture and Agri-Food Canada, Saskatoon, for L. maculans GL-11; Syngenta Crop Protection Canada, Inc., Guelph, for BTH; S. Abrams for advice on SA quantification; C. Chubak, C. Delong, J. Enns, and T. Wignes for technical assistance; and G. Liu for advice on assessing disease symptoms and for critical reading of the manuscript. This research was supported by a University of Saskatchewan New Faculty Dean Scholarship and Graduate Teaching Fellowship to S. D. Potlakayala, a National Science and Engineering Research Council Canada (NSERC) discovery grant to P. R. Fobert, and NRC PBI core funding. This is NRCC publication 46611.

\section{LITERATURE CITED}

1. Borges, A. A., Cools, H. J., and Lucas, J. A. 2003. Menadione sodium bisulphate: A novel plant defense activator which enhances local and systemic resistance to infection by Leptosphaeria maculans in oil seed rape. Plant Pathol. 52:429-436.

2. Cameron, R. K., Dixon, R. A., and Lamb, C. 1994. Biologically induced systemic acquired resistance in Arabidopsis thaliana. Plant J. 5:715-725.

3. Cameron, R. K., Paiva, N. L., Lamb, C. J., and Dixon, R. A. 1999. Accumulation of salicylic acid and $P R-1$ gene transcripts in relation to the systemic acquired resistance (SAR) response induced by Pseudomonas syringae pv. tomato in Arabidopsis. Physiol. Mol. Plant Pathol. 55:121130.

4. Cheong, N. E., Choi, Y. O., Kim, W. Y., Kim, S. C., Cho, M. J., and Lee, S. Y. 1997. Purification of an antifungal PR-5 protein from flower buds of Brassica campestris and cloning of its gene. Physiol. Plantarum 101:583590.

5. Delaney, T. P., Uknes, S., Vernooij, B., Friedrich, L., Weymann, K., Negrotto, D., Gaffney, T., Gur-Rella, M., Kessmann, H., Ward, E., and Ryals, J. 1994. A central role of salicylic acid in plant disease resistance. Science 266:1247-1250.

6. Dempsey, D. A., Shah, J., and Klessig, D. F. 1999. Salicylic acid and disease resistance in plants. Crit. Rev. Plant Sci. 18:547-575.

7. Durrant, W. E., and Dong, X. 2004. Systemic acquired resistance. Annu. Rev. Phytopathol. 42:185-209.

8. Engelberth, J., Schmelz, E. A., Alborn, H. T., Cardoza, Y. J., Huang, J., and Tumlinson, J. H. 2003. Simultaneous quantification of jasmonic acid and salicylic acid in plants by vapor-phase extraction and gas chromatography-chemical ionization-mass spectrometry. Anal. Biochem. 312:242250.

9. Friedrich, L., Lawton, K., Ruess, W., Masner, P., Specker, N., Gut-Rella, M., Meier, B., Dincher, S., Staub, T. Uknes, S., Métraux, J. P., Kessmann, H., and Ryals, J. 1996. A benzothiadiazole derivative induces systemic acquired resistance in tobacco. Plant J. 10:61-70.

10. Fristensky, B., Balcerzak, M., Daifen, H., and Zhang, P. 1999. Expressed sequence tags from the defense response of Brassica napus L. to Leptosphaeria maculans. Mol. Plant Pathol. Online. 1999/0301fristensky.

11. Gaffney, T., Friedrich, L., Vernooij, B., Negrotto, D., Nye, G., Uknes, S., Ward, E., Kessman, H., and Ryals, J. 1993. Requiremenet of salicylic acid for the induction of systemic acquired resistance. Science 261:754-756.

12. Godard, J. F., Ziadi, S., Monot, C., Le Corre, D., and Silue, D. 1999. Benzothiadiazole (BTH) induces resistance in cauliflower (Brassica oleracea var. botrytis) to downy mildew of crucifers caused by Peronospora parasitica. Crop Prot. 18:397-405.

13. Hammerschmidt, R., and Becker, J. S. 1997. Acquired resistance to disease in plants. Hortic. Rev. 18:247-288.

14. Hennin, C., Höfte, M., and Diederichsen, E. 2001. Functional expression of $C f 9$ and Avr9 genes in Brassica napus induces enhanced resistance to Leptosphaeria maculans. Mol. Plant-Microbe Interact. 14:1075-1085.

15. Howlett, B. J., Idnurm, A., and Pedras, M. S. 2001. Leptosphaeria maculans, the causal agent of blackleg disease of Brassicas. Fungal Genet. Biol. 33:1-14.

16. Jefferson, R. A., Kavanagh, T. A., and Bevan, M. W. 1987. GUS fusions: Beta-glucuronidase as a sensitive and versatile gene fusion marker in higher plants. EMBO J. 6:3901-3907.
17. Jensen, B. D., Latunde-Dada, A. O., Hudson, D., and Lucas, J. A. 1998. Protection of Brassica seedlings against downy mildew and damping-off by seed treatment with CGA 245704, an activator of systemic acquired resistance. Pestic. Sci. 52:63-69.

18. Kuć, J. 1982. Induced immunity to plant diseases. BioScience 32:854860.

19. Kumar, D., and Klessig, D. F. 2003. High-affinity salicylic acid-binding protein 2 is required for plant innate immunity and has salicylic acidstimulated lipase activity. Proc. Natl. Acad. Sci. USA. 100:16101-16106.

20. Lawton, K. A., Friedrich, L., Hunt, M., Weymann, K., Delaney, T., Kessmann, H., Staub, T., and Ryals, J. 1996. Benzothiadiazole induces disease resistance in Arabidopsis by activation of the systemic acquired resistance signal transduction pathway. Plant J. 10:71-82.

21. Lawton, K., Weymann, K., Friedrich, L., Vernooij, B., Uknes, S., and Ryals, J. 1995. Systemic acquired resistance in Arabidopsis requires salicylic acid but not ethylene. Mol. Plant-Microbe Interact. 8:863-870.

22. Liu, G., Holub, E. B., Alonso, J. M., Ecker, J. R., and Fobert, P. R. 2005. An Arabidopsis NPR1-like gene, NPR4, is required for disease resistance. Plant J. 41:304-318.

23. Mahuku, G, S., Hall, R., and Goodwin, P.H. 1996. Co-infection and induction of systemic acquired resistance by weakly and highly virulent isolates of Leptosphaeria maculans in oil seed rape. Physiol. Mol. Plant Pathol. 49:61-72.

24. Maldonado, A. M., Doerner, P., Dixon, R. A., Lamb, C. J., and Cameron, R. K. 2002. A putative lipid transfer protein involved in systemic resistance signaling in Arabidopsis. Nature 419:399-403.

25. Nawrath, C., and Métraux, J. P. 1999. Salicylic acid induction-deficient mutants of Arabidopsis express $P R-2$ and $P R-5$ and accumulate high levels of camalexin after pathogen inoculation. Plant Cell 11:1393-1404.

26. Newman, M., Conrads-Strauch, J., Scofield, G., Daniels, M. J. and Dow, J. M. 1994. Defense-related gene induction in Brassica campestris in response to defined mutants of Xanthomonas campestris with altered pathogenicity. Mol. Plant-Microbe Interact. 7:553-563.

27. Polowick, P. L., Quandt, J., and Mahon, J. D. 2000. The ability of pea transformation technology to transfer genes into peas adapted to western Canadian growing conditions. Plant Sci. 153:161-170.

28. Ryals, J., Neuenschwander, U. H., Willitis, M. G., Molina, A., Steiner, H, Y., and Hunt, M. D. 1996. Systemic acquired resistance. Plant Cell 8:1809-1819.

29. Sambrook, J., Fritsch, E.F. and Maniatis, T. 1989. Bacterial media, Antibiotics, and Bacterial Strains. Page A.3 in: Molecular Cloning: A Laboratory Manual. 2nd ed. Cold Spring Harbor Laboratory Press, Cold Spring Harbor, NY.

30. Sticher, L., Mauch-Mani, B., and Métraux, J. P. 1997. Systemic acquired resistance. Annu. Rev. Phytopathol. 35:235-270.

31. Tao, Y., Xie, Z., Chen, W., Glazebrook, J., Chang, H. S., Han, B., Zhu, T., Zou, G., and Katagiri, F. 2003. Quantitative nature of Arabidopsis responses during compatible and incompatible interactions with the bacterial pathogen Pseudomonas syringae. Plant Cell 15:317-330.

32. Tsang, E. W. T., Yang, J., Chang, Q., Nowak, G., Kolenovsky, A., McGregor, I. D., and Keller, W. A. 2003. Chlorophyll reduction in the seed of Brassica napus with a glutamate 1-semialdehyde aminotransferase antisense gene. Plant Mol. Biol. 51:191-201.

33. Uknes, S., Mauch-Mani, B., Moyer, M., Potter, S., Williams, S., Dincher, S., Chandler, D., Slusarenko, A., Ward, E., and Ryals, J. 1992. Acquired resistance in Arabidopsis. Plant Cell 4:645-656.

34. Verberne, M. C., Brouwer, N., Delbianco, F., Linthorst, H. J. M., Bol, J. F., and Verpoorte, R. 2002. Method for the extraction of the volatile compound salicylic acid from tobacco leaf material. Phytochem. Analysis 13:45-50.

35. Ward, E. R., Uknes, S. J., Williams, S. C., Dincher, S. S., Wiederhold, D. L., Alexander, D. C., Ahl-Goy, P., Métraux, J.-P., and Ryals, J. A. 1991. Coordinate gene activity in response to agents that induce systemic acquired resistance. Plant Cell 3:1085-1094.

36. Witte, R. S. 1989. Tests for two independent samples. Pages 259-279 in: Statistics. 3rd ed. Holt, Rinehart, and Winston, Inc., The Dryden Press, New York.

37. Yalpani, N., Silverman, P., Wilson, T. M. A., Kleier, D. A., and Raskin, I. 1991. Salicylic acid is a systemic signal and an inducer of pathogenesisrelated proteins in virus-infected tobacco. Plant Cell 3:809-818.

38. Ziadi, S., Barbedette, S., Godard, J. F., Monot, C., Le Corre, D., and Silue, D. 2001. Production of pathogenesis related proteins in the cauliflower (Brassica oleracea var. botrytis) - downy mildew (Peronospora parasitica) pathosystem treated with acibenzolar-S-methyl. Plant Pathol. 50:579-586. 